\title{
A CpG oligodeoxynucleotide enhances the immune response to rabies vaccination in mice
}

\author{
Pengcheng Yư ${ }^{\dagger}$, Jianghong Yan ${ }^{\dagger}$, Weicheng Wu, Xiaoyan Tao, Xuexin Lu, Shuqing Liu and Wuyang Zhu*
}

\begin{abstract}
Background: Rabies is a fatal disease that is preventable when post exposure prophylaxis (PEP) is administered in a timely fashion. CpG oligodeoxynucleotides (ODNs) can trigger cells that express Toll-like receptor 9, and their immunopotentiation activity in an inactivated aluminum-adjuvanted rabies vaccine for dogs has been identified using mouse and dog models.
\end{abstract}

Methods: A human diploid cell rabies vaccine (HDCV) of humans and a CpG ODNs with cross-immunostimulatory activity in humans and mice were used to evaluate the immunogenicity and protective efficacy of CpG ODN in a mouse model that simulates human PEP.

Results: HDCV combined with CpG ODN (HDCV-CpG) stimulated mice to produce rabies virus-specific neutralizing antibody (RVNA) earlier and increased the seroconversion rate. Compared with HDCV alone, either HDCV-1.25 $\mu \mathrm{g}$ CpG or HDCV-5 $\mu \mathrm{g}$ CpG increased the levels of RVNA. In particular, $5 \mu \mathrm{g}$ CpG ODN per mouse significantly boosted the levels of RVNA compared with HDCV alone. IFN- $\gamma$ producing splenocytes generated in the HDCV-5 $\mu \mathrm{g}$ CpG group were significantly increased compared to the group treated with HDCV alone. When the immunization regimen was reduced to three injections or the dose was reduced to half of the recommended HDCV combined with CpG ODN, the RVNA titers were still higher than those induced by HDCV alone. After viral challenge, 50\% of mice immunized with a half-dose HDCV-CpG survived, while the survival rate of mice immunized with HDCV alone was $30 \%$.

Conclusions: The immunopotentiation activity of $\mathrm{CpG}$ ODNs for a commercially available human rabies vaccine was first evaluated in a mouse model on the basis of the Essen regimen. Our results suggest that the CpG ODN used in this study is a potential adjuvant to rabies vaccines for human use.

Keywords: CpG ODN, HDCV, Immunization

\section{Introduction}

Rabies is caused by lyssaviruses and is almost always fatal following the onset of clinical symptoms. Approximately 59,000 humans die from rabies each year [1]. Pre- or post-exposure rabies vaccination is the only treatment to prevent rabies in humans. Rabies is $100 \%$ preventable by timely administration of post exposure prophylaxis (PEP) to bite victims, but fatalities still occur in many countries in which rabies is endemic [2-4]. In

\footnotetext{
* Correspondence: zhuwuyang1971@sina.com

${ }^{\dagger}$ Pengcheng Yu and Jianghong Yan contributed equally to this work. Key Laboratory for Medical Virology, Ministry of Health, National Institute for Viral Disease Control and Prevention, Chinese Center for Disease Control and Prevention, Beijing, China
}

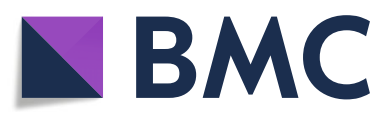

(c) The Author(s). 2018 Open Access This article is distributed under the terms of the Creative Commons Attribution 4.0 International License (http://creativecommons.org/licenses/by/4.0/), which permits unrestricted use, distribution, and reproduction in any medium, provided you give appropriate credit to the original author(s) and the source, provide a link to the Creative Commons license, and indicate if changes were made. The Creative Commons Public Domain Dedication waiver (http://creativecommons.org/publicdomain/zero/1.0/) applies to the data made available in this article, unless otherwise stated.
China, more than 12 million people every year are inoculated with the rabies vaccine for pre-exposure prophylaxis (PrEP) or PEP [5]. The development of more effective and productive rabies vaccines for human use is urgently needed because of the high incidence of rabies and the large dosages needed for current pre- or post-exposure rabies vaccination.

Prior to 1980, the rabies vaccine for human use was produced from sheep brain tissue and induced severe adverse effects such as neuroparalysis and encephalomyelitis. In 1980, China abandoned the animal brain tissue vaccine in favor of a cell-culture vaccine. Presently, the widely used rabies vaccines for human prophylaxis in 
China are cell-culture vaccines, such as the human diploid cell rabies vaccine (HDCV), purified chicken embryo cell rabies vaccine (PCECV), purified Vero cell rabies vaccine (PVRV) [6] and the primary hamster kidney cell culture vaccine (PHKCV). In our study, we used HDCV which contains the Pitman-Moore strain of rabies virus grown on MRC- 5 human diploid cell culture and is concentrated by ultrafiltration and inactivated with B-propiolactone.

An adjuvant is added to a vaccine to boost the immune response to induce higher levels of antibodies and longer-lasting protection, which can consequently reduce the amount of vaccine required. Aluminum is the first adjuvant approved by the U.S. Food and Drug Administration (FDA) for human vaccines, which was once used for improving the immunogenicity of human rabies vaccines such as PHKCV. An effective rabies vaccine should induce sufficient early RVNA to arrest rabies virus infection. Although the aluminum adjuvant can improve antibody titers to the rabies vaccine, it is argued to delay the early production of antibodies, which may be very unfavorable for the prevention of rabies [7]. As a result, and the China Food and Drug Administration banned the use of aluminum hydroxide $\left(\mathrm{Al}(\mathrm{OH})_{3}\right)$ adjuvant for the human rabies vaccine on June 30, 2005. Therefore, identifying a safe, effective, and selective adjuvant for rabies vaccines is necessary.

CpG oligodeoxynucleotides (CpG ODNs) are short synthetic single-stranded DNA molecules containing unmethylated $\mathrm{CpG}$ dinucleotides in particular sequence contexts (CpG motifs). CpG ODNs can trigger cells that express Toll-like receptor 9 (including human plasmacytoid dendritic cells and B cells) to mount an innate immune response characterized by the production of $\mathrm{T}$ helper 1 and proinflammatory cytokines [8]. CpG ODNs coadministered with vaccines improve the function of professional antigen-presenting cells and boost the generation of humoral and cellular vaccine-specific immune responses [9-14]. It was reported that CpG ODNs could facilitate more vigorous RVNA responses to an inactivated aluminum-adjuvanted rabies vaccine in mice and dogs $[15,16]$. In our study, we evaluated the immunopotentiation and protective efficacy provided in mice by injecting HDCV combined with CpG ODN.

\section{Materials and methods \\ CpG ODN}

The ODN (5'-TCG ACG TTC GTC GTT CGT CGT TC-3') used in this study was synthesized by Takara Biotech Company (Dalian, China) and was diluted with endotoxin-free water and vortexed until completely dissolved.

\section{Cells and animals}

BSR cells (a cloned baby hamster kidney cell line) were cultured at $37{ }^{\circ} \mathrm{C}$ in a $5 \% \mathrm{CO}_{2}$ humidified incubator and maintained in Dulbecco's minimum essential medium (Gibco, Waltham, MA USA) supplemented with 10\% ( $\mathrm{v} /$ v) heat inactivated fetal bovine serum (FBS, Gibco) and $1 \%(\mathrm{v} / \mathrm{v})$ antibiotics (100 IU of penicillin/ml and $100 \mathrm{IU}$ of streptomycin/ml, Gibco).

Specific pathogen-free (SPF) female BALB/c mice were purchased from the Vital River Laboratory Animal Technology Co., Ltd., Beijing and kept under individual ventilated cages (IVC) for all experiments. All animals were treated according to the regulations of Chinese law and the Animal Experimental Ethical Inspection of the National Institute for Viral Control and Prevention of China CDC.

\section{Vaccines, standards, and viruses}

Freeze-dried HDCV for human use was produced by Chengdu Kanghua Biological Products Co., Ltd. For use, HDCV containing at least 2.5 IU rabies virus was reconstituted with $1.0 \mathrm{ml}$ of water for injection.

A national reference standard serum $(30 \mathrm{IU} / \mathrm{ml})$ was purchased from the National Institute for Biological Standards and Control (UK). Anti-rabies nucleoprotein antibody labeled with fluorescein isothiocyanate was purchased from Fujirebio Diagnostics, Inc. The standard challenge virus (CVS-11) was provided by the National Institutes for Food and Drug Control, China. CVS-11 was propagated in BSR cells and the median lethal dose $\left(\mathrm{LD}_{50}\right)$ in $\mathrm{BALB} / \mathrm{c}$ mice was previously determined by the intramuscular (i.m.) injection route.

\section{MTT colorimetric assay for the activity of ODNs}

A 3-(4,5-dimethylthiazol-2-yl)-2,5-diphenyltetrazolium bromide (MTT) cell proliferation and cytotoxicity assay kit (Solarbio, Beijing, China) was used to detect the activity of CpG ODN. Splenocytes from female BALB/c mice were stimulated with $6 \mu \mathrm{l}$ of CpG ODN $(100 \mu \mathrm{g} /$ $\mathrm{ml}$ ) or PBS and incubated for $36 \mathrm{~h}$ at $37{ }^{\circ} \mathrm{C}$ in $5 \% \mathrm{CO}_{2}$. One hundred microliters of supernatant was replaced by fresh medium, and $10 \mu \mathrm{l} \mathrm{MTT}(5 \mathrm{mg} / \mathrm{ml})$ was then added and incubated for $4 \mathrm{~h}$. The supernatant was discarded, $150 \mu \mathrm{l}$ dimethylsulfoxide was added, and cultures were shaken gently to dissolve the crystals. The absorbance of each well at $570 \mathrm{~nm}$ was measured using a plate reader.

\section{Immunization}

Mice (6-8 weeks old, weight $18-22$ g) were immunized by i.m. injection to the right leg of $100 \mu \mathrm{l}$ of HDCV diluted 50 times [17]. The preparations were injected into mice using the Essen regimen (five separate doses on days $0,3,7,14$, and 28), which is one of the PEP schedules 
recommended by the World Health Organization (WHO) [18]. Serum samples were collected and separated by centrifugation at $4000 \mathrm{rpm}$ for $10 \mathrm{~min}$ and stored at $-20{ }^{\circ} \mathrm{C}$ until testing. The RVNA titers were evaluated using the rapid fluorescent focus inhibition test (RFFIT), a standardized test recommended by the WHO.

\section{Evaluation of cellular immune response}

Mice were sacrificed at day 14 after the first immunization, and splenocytes were prepared. The frequency of IFN- $\gamma$-secreting cells was analyzed using commercial mouse IFN- $\gamma$ ELISPOT kits (BD, America) following the manufacturer's instructions. Spots were counted using an automated ELISPOT reader (BioSystems). The mean spot number \pm SD of triplicate wells for each stimulation antigen or control was calculated.

\section{Rapid fluorescent focus inhibition test}

Challenge virus standard (CVS-11), at the dose that caused $80 \%$ infection of BSR cells after 24 h, was incubated with serial dilutions of the sera to be titrated. A reference serum $(30 \mathrm{IU} / \mathrm{ml})$ was included in each test. After $1 \mathrm{~h}$ of incubation at $37^{\circ} \mathrm{C}$, BSR cells were added to each well. After $24 \mathrm{~h}$ of incubation at $37{ }^{\circ} \mathrm{C}$ in $5 \% \mathrm{CO}_{2}$, the percentage of infected cells at each serum dilution was estimated. This allowed the determination of the titer of the unknown neutralizing antibodies by comparison with the reference serum. The titer of the neutralizing antibodies in the sera was recorded in $\mathrm{IU} / \mathrm{ml}$, which is the global standard. Serum with a neutralizing antibody titer $\geq 0.5 \mathrm{IU} / \mathrm{ml}$ was considered positive.

\section{Statistical analysis}

Statistical analysis and graphing were performed using commercially available software (GraphPad Prism 5.0). Specifically, unpaired two-tailed Student's t-tests were applied to analyze the data and to evaluate the antibody levels expressed as geometric mean titers \pm standard deviation $(\mathrm{GMT} \pm$ S.D.). A $P$-value $<0.05$ was considered statistically significant.

\section{Results}

\section{Activity of $\mathrm{CpG}$ ODN for mouse splenic lymphocytes}

An MTT cell proliferation and cytotoxicity assay kit was used to assess the activity of CpG ODN. The kit defines the stimulation index (SI) as the average value of the optical density (OD) in experimental wells divided by the average OD value in control wells. SI $>1.5$ was considered to indicate specific proliferation of lymphocytes [19]. The average ODs of the CpG ODN group and the PBS group were 1.581 and 0.827 , respectively. Therefore, the SI was 1.91, indicating that CpG ODN could stimulate the splenocytes in vitro, thereby enhancing the immune response.

\section{Immunogenicity of different doses of HDCV-CpG}

To determine the enhancing effect of CpG ODN on the immunogenicity of the HDCV rabies vaccine, female $\mathrm{BALB} / \mathrm{c}$ mice $(n=10)$ were immunized i.m. with HDCV combined with different doses of CpG ODN (1.25 $\mu \mathrm{g}$, $5 \mu \mathrm{g}$, or $20 \mu \mathrm{g}$ per mouse) using the Essen regimen. Serum samples were collected on days $0,6,8,10,14,45$ and 90. The RVNA in the sera of immunized mice was detected using the RFFIT method and reported as IU/ $\mathrm{ml}$. The preimmune sera of the mice were used as negative controls.

Seroconversion means the RVNA titer is equal to or greater than $0.5 \mathrm{IU} / \mathrm{ml}$, which is regarded as an adequate immune response for protection by the WHO. As shown in Fig. 1, on D8 and D10 after the first immunization, the rates of seroconversion in the HDCV+1.25 $\mu \mathrm{g}$ CpG and $\mathrm{HDCV}+5 \mu \mathrm{g} \mathrm{CpG}$ groups were 40 and $60 \%$, respectively, while those in the HDCV alone and HDCV+ $20 \mu \mathrm{g}$ CpG groups were both zero. On D10, the seroconversion rates of the $\mathrm{HDCV}+1.25 \mu \mathrm{g} \mathrm{CpG}$ and $\mathrm{HDCV}+$ $5 \mathrm{~g}$ CpG groups were both $100 \%$, while those of the $\mathrm{HDCV}$ alone and $\mathrm{HDCV}+20 \mu \mathrm{g}$ CpG groups were both $80 \%$. On D14 and D45, all four groups showed $100 \%$ seroconversion. These results indicate that the $\mathrm{CpG}$ ODN adjuvant can stimulate mice to produce RVNA earlier and increase the seroconversion rate.

As shown in Fig. 2, either HDCV-1.25 $\mu \mathrm{g}$ CpG or HDCV $-5 \mu \mathrm{g}$ CpG can increase the level of RVNA than that induced by $\mathrm{HDCV}$ alone. On D8 after the first immunization, the GMT of RVNA induced by HDCV+ $5 \mu \mathrm{g}$ CpG reached $0.6 \mathrm{IU} / \mathrm{ml}$, which was significantly different $(P<0.05)$ than the HDCV alone group. Consistently, HDCV $+5 \mu \mathrm{g}$ CpG stimulated a significant level of RVNA on D10, 14, 30, 45 and 90. Compared with the HDCV groups, the GMT of the HDCV+1.25 $\mu \mathrm{g}$ CpG groups also showed significant differences on D30 and D60 $(P<0.01)$. Compared with these two groups, the GMTs from the HDCV+20 $\mu \mathrm{g}$ CpG group showed no significant differences at any of the 8 points of serum collection. These results indicate that $5 \mu \mathrm{g} \mathrm{CpG}$ per mouse is optimal to facilitate production of a stronger RVNA response in mice.

\section{Cellular immune response in vaccinated mice}

To determine whether $\mathrm{T}$ cells were activated, the frequencies of IFN- $\gamma$-producing cells at the single-cell level were determined by ELISPOT assay following stimulation of mouse spleen lymphocytes with HDCV and HDCV combined with CpG ODN. The HDCV-5 $\mu \mathrm{g}$ CpG group generated approximately $500 \mathrm{SFU} / 5 \times 10^{5}$ of IFN- $\gamma$-specific splenocytes (Fig. 3), which was significantly higher than the group treated with HDCV alone. Similarly, the numbers of IFN- $\gamma$-secreting cells generated in mice primed with $\mathrm{HDCV}+1.25 \mu \mathrm{g} \mathrm{CpG}$ and $\mathrm{HDCV}+1.25 \mu \mathrm{g}$ CpG 


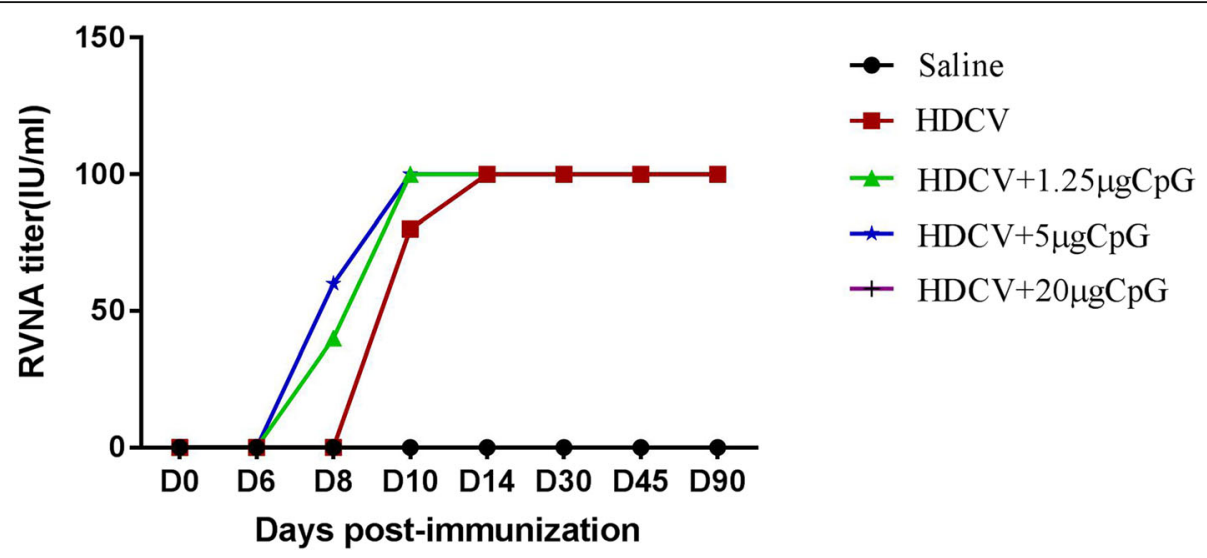

Fig. 1 Positive conversion by different doses of CpG combined with RV. HDCV, Saline, and HDCV plus CpG at 1.25, 5 and $20 \mu$, respectively, were used as vaccines. Balb/c mice $(n=10)$ were immunized i.m. with the above vaccines on D0, 3, 7, 14, and 28 . Serum samples were collected on D0, 6, 8, 10, 14, 30, 45 and 90. RFFIT was used to detect RVNA in the sera of mice

groups were also significantly different from those in the HDCV group.

\section{RVNA response induced by reduced injections of HDCV-CpG}

To evaluate the possibility of reducing the number of injections required for immunization with $\mathrm{HDCV}-\mathrm{CpG}$, mice $(n=10)$ were immunized i.m. 5 times with HDCV or $5,4,3$, or 2 times with $\mathrm{HDCV}-\mathrm{CpG}$, reported as HDCV-5, HDCV-CpG-5, HDCV-CpG-4, HDCVCpG-3, and HDCV-CpG-2, respectively. The HDCV-5 and HDCV-CpG-5 groups were immunized using the Essen regimen. The HDCV-CpG-4 group was injected on D0, 3, 7 and 14; the HDCV-CpG-3 group, on D0, 3 and 7; and the HDCV-CpG-2 group on D0 and 3. The dose of CpG ODN used was $5 \mu \mathrm{g} /$ mouse. On D35 after the first immunization, sera were collected from the retroorbital sinus of mice, and RVNA in the sera was measured using RFFIT.

As shown in Fig. 4, the GMTs of the HDCV-CpG-5 and HDCV-CpG-4 groups were all significantly higher $(P<0.05)$ than that of HDCV-5 group, which was injected five times with HDCV alone. HDCV-CpG-3 stimulated mice to produce similar levels of RVNA similar to those of the HDCV-5 group, and there was no statisticant difference between the GMTs from the two groups $(P>0.05)$. Although the RVNA titer of the HDCV-CpG-2 group was lower than that of HDCV-5, all tested sera were above $0.5 \mathrm{IU} / \mathrm{ml}$. These results indicate that $\mathrm{CPG}$ ODN can enhance RVNA production in response to $\mathrm{HDCV}$ and maintain similar RVNA levels even when the number of injections is reduced to two.

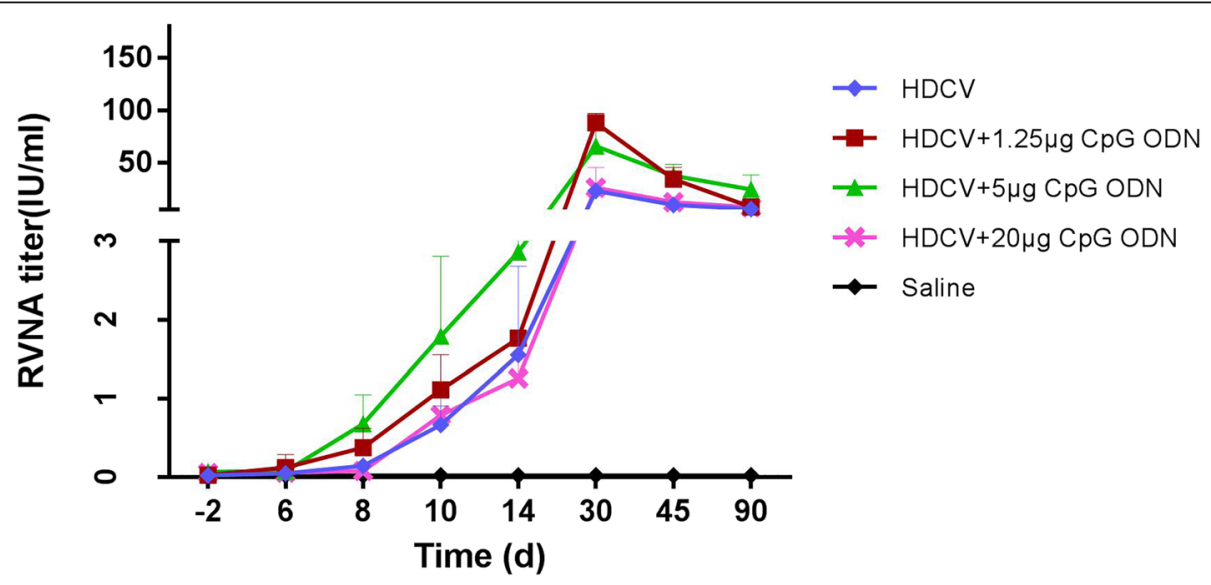

Fig. 2 Effect of immunization on CpG combined with HDCV. HDCV, Saline, and HDCV plus CpG at 1.25, 5 and $20 \mu \mathrm{g}$, respectively, were used as vaccines. Balb/c mice $(n=10)$ were immunized i.m. with the above vaccines on D0, 3, 7, 14, and 28. Serum samples were collected on D0, 6, 8, $10,14,30,45$ and 90 . RFFIT was used to detect RVNA in the sera of mice. The antibody titer was expressed in international units per milliliter $(\mathrm{IU} / \mathrm{ml})$, calculated in comparison with the national reference standard serum 


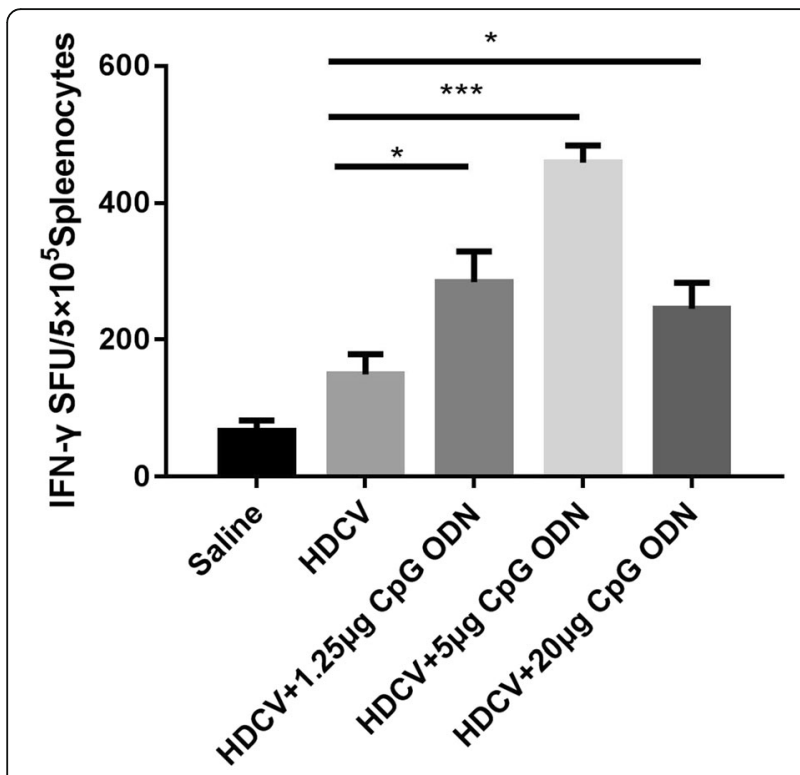

Fig. 3 Cellular immune response in vaccinated mice. Splenocytes from immunized mice were isolated 14 days after the first immunization. The figure showes the number of IFN- $\gamma$-secreting cells as determined by ELISPOT assay. The data are expressed as the means \pm SEM $(n=5$; $\left.{ }^{*} P<0.05,{ }^{* *} P<0.01,{ }^{* *} P<0.001\right)$

RVNA response induced by a reduced dose of HDCV-CpG To evaluate the possibility of reducing the immunizing dose of HDCV-CpG, mice $(n=10)$ were immunized i.m. with $\mathrm{HDCV}$ alone or with $\mathrm{CpG}$ ODN combined with a full dose of HDCV, a half dose of HDCV, a quarter dose of HDCV or an eighth dose of HDCV, reported

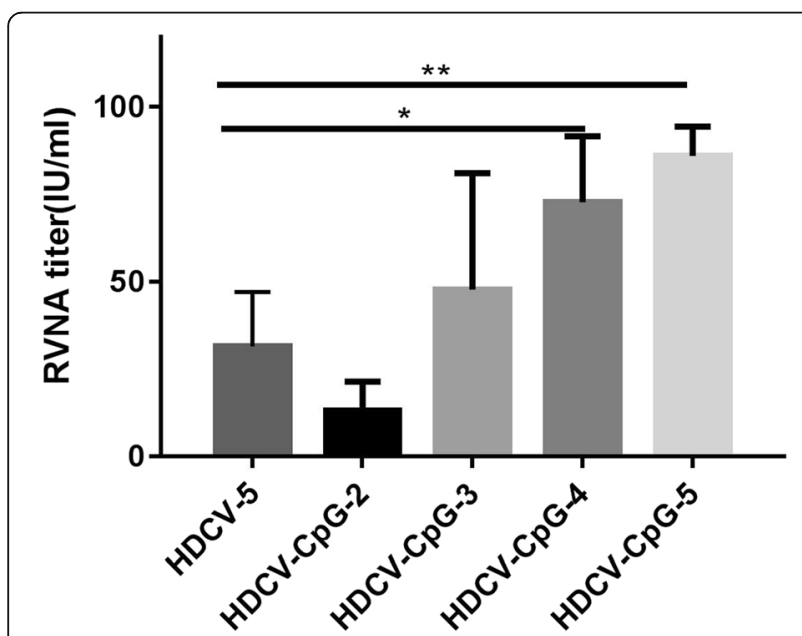

Fig. 4 RVNA response induced by reduced injections of HDCV-CpG. Balb/c mice $(n=10)$ were immunized i.m. with HDCV for 5 injections and HDCV plus CpG for 5, 4, 3 and 2 injections. Serum samples were collected on D35. RFFIT was used to detect RVNA in the sera of mice. The antibody titer was expressed in international units per milliliter $(I U / \mathrm{ml})$, calculated in comparison with the national reference standard serum as HDCV, HDCV-CpG, 1/2HDCV-CpG, 1/4HDCV$\mathrm{CpG}$, and 1/8HDCV-CpG, respectively. All groups were immunized using the Essen regimen, and the dose of CpG ODN was $5 \mu \mathrm{g} /$ mouse. On D35 after the first immunization, sera were collected and the RVNA titers in the sera were measured by RFFIT.

As shown in Fig. 5, a half dose of HDCV with CpG induced the highest RVNA titers of all tested groups, which was significantly higher than that in the group immunized with HDCV alone $(P<0.05)$. Even when the dose of HDCV was reduced to one-eighth, the RVNA titer was positive in all mice and not significantly different from that in the HDCV group $(P>0.05)$. This result indicate that $\mathrm{CpG}$ ODN can enhance the immunogenicity of HDCV and stimulate mice to produce similar RVNA levels even if the dose of HDCV is reduced to one-eighth.

\section{Protection of immunized animals against rabies virus challenge}

To test whether the HDCV-CpG could elicit adequate protective immunity against a robust rabies virus challenge in an animal model, CVS-11 was prepared for infection at $50 \mathrm{LD}_{50}$ on the hind leg. After $2 \mathrm{~h}$, all groups (Saline, HDCV, HDCV+CpG, HDCV+1/2 CpG, HDCV $+1 / 4 \mathrm{CpG}$ and $\mathrm{HDCV}+1 / 8 \mathrm{CpG}$ ) were immunized with 5 injections. BALB/c mice in all test groups behaved normally for 6 days after the infection. Infected mice did not survive once clinical symptoms such as decreased

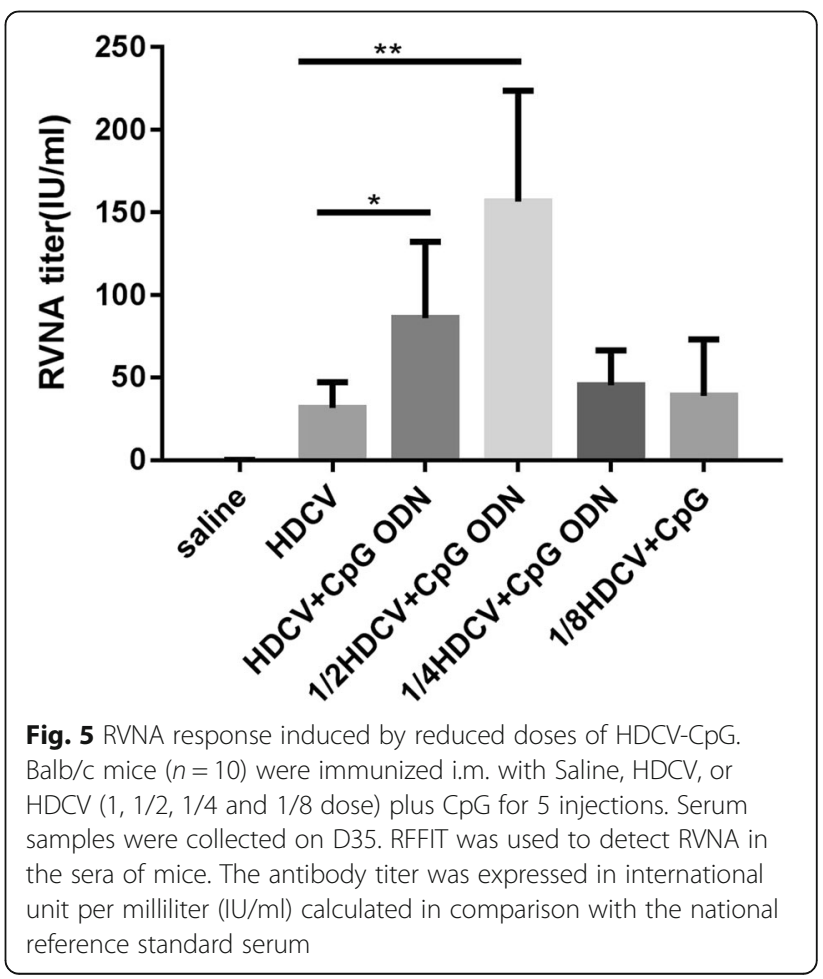


activity, clumsiness, poor coordination, decreased food intake and anxiety, appeared between day 7 and 16, and all mice died within 4-6 days after the onset of abnormal symptoms. Densely distributed florescent spots were observed in the direct fluorescence antibody test, indicating that death was caused by rabies viral infection of the central nervous system.

The survival rates for all test groups are shown in Fig. 6. The majority (70\%) of mice in the HDCV group died after viral challenge, whereas the HDCV-CpG group was better protected, with only $50 \%$ of mice dying. Furthermore, the survival rates of the $1 / 2 \mathrm{HDCV}-\mathrm{CpG}$ group $(40 \%)$ and the $1 / 4 \mathrm{HDCV}-\mathrm{CpG}$ group $(40 \%)$ were both higher than that of the HDCV group (30\%). These results indicated that HDCV combined with CpG ODN stimulates mice to produce RVNA earlier, which protects the mice from early death.

\section{Discussion}

CpG ODNs have been reported to boost the humoral immune response induced by vaccines against a large number of pathogens, including anthrax, Leishmania, influenza virus, measles virus, lymphocytic choriomeningitis virus, orthopoxviruses, hepatitis B surface antigen, and tetanus toxoid, improving antigen-specific antibody titers by up to three orders of magnitude [20-28]. Several studies have indicated that $\mathrm{CpG}$ ODNs accelerate the development of vaccine-induced responses. For example, mice vaccinated with CpG-adjuvanted anthrax vaccine-adsorbed (AVA) developed protective immunity three times faster than those immunized with AVA alone, with significant protection observed within 5 versus 15 days $(P<0.05)$. The combination of CpG ODN with AVA accelerated the serum IgG anti-Bacillus anthracis (BA) response, yielding serum anti-BA titers that were ten-fold higher and significantly more protective by day $10(P<0.05)$ [29]. In another study, administering CpG ODN with recombinant herpes simplex virus (HSV)-1 glycoprotein B intranasally induced significant levels of glycoprotein B-specific IgA and anti-HSV cytotoxic $\mathrm{T}$ lymphocytes in the genital tract and protected mice from genital HSV challenge [30].

Studies have shown that the rabies virus attacks the nervous tissue and appears to replicate almost exclusively in neuronal cells. Once introduced through the skin or mucous membrane, the virus begins to replicate in striated muscles at the wound site. To block the rapid replication and migration of rabies virus, vaccines should be administered to activate the immune system as soon as possible. Especially when the bite is on the face or head, the early induction of RVNA is important to save lives. Unlike other diseases, rabies is almost always fatal but preventable with an incubation period of 13 months. This feature allows time for post-exposure treatment with the rabies vaccine to induce RVNA and to neutralize the rabies virus. Therefore, it is important to induce an earlier and higher RVNA response with rabies vaccines. In this study, we demonstrated that HDCV combined with CPG ODN could improve the seroconversion rate and RVNA titer in a mouse model. In particular, $5 \mu \mathrm{g}$ CpG per mouse was optimal to enhance immunopotentiation of HDCV because HDCV$5 \mu \mathrm{g}$ CpG could increase the seroconversion rate and produce significantly higher RVNA levels in mice. Interestingly, the HDCV+ $20 \mu \mathrm{g}$ CpG group had a lower rate of seroconversion and lower GMT of RVNA, perhaps due to damage caused by the high dose of CpG to the spleen (Additional file 1: Figure S1), which is the most important organ for humoral immunity. In addition, we observed that even one-quarter of the recommended dose of HDCV combined with CpG ODN induced better protection than HDCV alone. This result also indicated

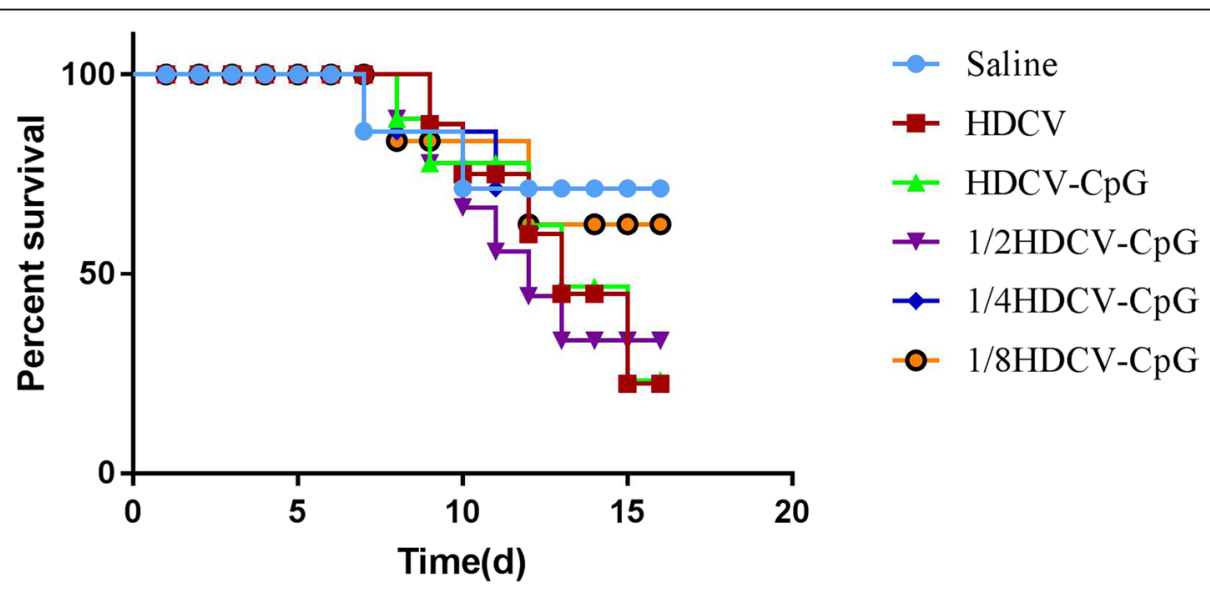

Fig. 6 Survival curve of different doses of HDCV combined with CpG. Balb/c mice $(n=10)$ were injected i.m. with CVS-11. On D0 of exposure, mice were immunized with HDCV or HDCV (1, 1/2,1/4 and 1/8 dose) plus CpG for 5 injections 
that in mice exposed to rabies virus that were administered HDCV combined with CpG ODN, RVNA was produced earlier and at higher levels than following immunization with HDCV alone.

Previous studies have shown that the TLR-9 molecule expressed by humans and mice differs by $24 \%$ at the amino acid level, and the cells that express TLR-9 vary between these species [31-34]. The motif (consisting of a CpG dinucleotide plus flanking regions) that optimally stimulates immune cells differs between mice and humans [35-38]. Although differences exist, another study demonstrated that mice may be used as an animal model to evaluate the activities of some human CpG ODN containing the 5'-GTCGTT-3' motif [39]. The core of the sequence (--TCGT--) of CpG ODN used in our study is the human CpG motif, which has strong activity to human immune cells. The CpG ODN with this motif had good adjuvant activity in phase I/II clinical studies of a synergistic hepatitis $B$ prophylactic vaccine [40]. Therefore, HDCV combined with CpG ODN in a mouse model simulating human PEP can facilitate production of an earlier, stronger, and longer-lasting RVNA response and can protect mice from rabies after exposure. These results could have a potential impact on human PEP, although the animal model is not suitable for the evaluation of human vaccines. The immunopotentiation and safety of the CpG ODN used in this study to a rabies vaccine for human use should be further evaluated with clinical trials in the future.

\section{Conclusions}

In this study, HDCV combined with $\mathrm{CpG}$ ODN in a mouse model simulating human PEP could facilitate production of an earlier, stronger, and longer-lasting RVNA response and protect mice from rabies after exposure to CVS-11. Further studies are needed to investigate the toxicity and side effects of CpG ODNs used in the mouse model. However, the results of this study suggest that $\mathrm{CpG}$ is a potential adjuvant for rabies vaccines for human use.

\section{Additional file}

Additional file 1: Figure S1. Histopathological changes of mice spleen.

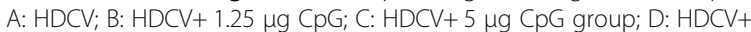
$20 \mu \mathrm{g} \mathrm{CpG}$ (HEX 400). To evaluate the safety of different doses of CpG ODN, we examined the morphological changes and pathological changes using hematoxylin and eosin stained spleen tissues collected at D14. (DOCX $456 \mathrm{~kb}$ )

\section{Abbreviations}

CVS: Challenge virus standard; GMT \pm S.D.: geometric mean titer \pm standard deviation; HDCV: human diploid cell rabies vaccine; ODN: oligodeoxynucleotid;
PCECV: purified chicken embryo cell rabies vaccine; PEP: post exposure prophylaxis; PHKCV: primary hamster kidney cell culture vaccine; PVRV: purified Vero cell rabies vaccine; RVNA: rabies virus-specific neutralizing antibody

\section{Acknowledgments}

Not applicable.

\section{Funding}

This work was supported by the National Program on Key Research Project of China (2016YFD0500400); The National Natural Science Foundation of China (31500152); National Key R\&D Program of China (2017YFC1200503); China Mega-Project for Infectious Disease (2017ZX10104001-004-001) and National Science and Technology Major Project (2018ZX10201002).

\section{Availability of data and materials}

The datasets supporting the conclusions of this article are included within the article.

\section{Authors' contributions}

PENGCHENG YU and JIANGHONG YAN performed the experiments, analyzed the data and wrote the paper. WEICHENG WU participated in the animal experiments. XIAOYAN TAO, SHUQING LIU and XUEXIN LU participated in design of study and data analysis. All authors read and approved the final manuscript. WUYANG ZHU designed the study and participated in the experiments.

\section{Ethics approval and consent to participate}

The program for immunization of HDCV combined with CPG ODN was approved (approval NO. 201510140028) by the Ethical Committee of the National Institute of Viral Disease Control and Prevention, China CDC. Animal care and use protocol in this study abided "The Guidance on Treating Experimental Animals" which promulgated by the ministry of science and technology of China. No non-human primates were used in this study.

\section{Consent for publication}

Not applicable.

\section{Competing interests}

The authors declare that they have no competing interests.

\section{Publisher's Note}

Springer Nature remains neutral with regard to jurisdictional claims in published maps and institutional affiliations.

Received: 12 March 2018 Accepted: 1 November 2018

Published online: 13 November 2018

\section{References}

1. Hampson K, Coudeville L, Lembo T, Sambo M, Kiefer A, Attlan M, et al. Estimating the global burden of endemic canine rabies. PLoS Negl Trop Dis. 2015;9(4):e0003709.

2. Wang S. A new PIKA adjuvant rabies vaccine-the therapeutic vaccine for life rescue. J Appl Prev Med. 2010;16(1):1-4.

3. Wilde H. Failures of post-exposure rabies prophylaxis. Vaccine. 2007;25(44): 7605-9.

4. Rupprecht CE, Briggs D, Brown CM, Franka R, Katz SL, Kerr HD, et al. Evidence for a 4-dose vaccine schedule for human rabies postexposure prophylaxis in previously non-vaccinated individuals. Vaccine. 2009;27(51): 7141-8.

5. Situation of rabies Prev Control in China. Ministry of Health of the People's Republic of China 2009.

6. Wiktor TH. Virus vaccines and therapeutic approaches. In: Bishop HD, editor Rhabdomyoviruses, Vol. 3. Boca Raton, FL: CRC Press; 1980. p. 99-112.

7. Lin $\mathrm{H}$, Perrin P. Influence of aluminum adjuvant to experimental rabies vaccine. Chin J Exp Clin Virol. 1999;13(2):133-5.

8. Bode C, Zhao G, Steinhagen F, Kinjo T, Klinman DM. CpG DNA as a vaccine adjuvant. Expert Rev Vaccine. 2011;10(4):499-511.

9. Stacey KJ, Blackwell JM. Immunostimulatory DNA as an adjuvant in vaccination against Leishmania major. Infect Immun. 1999;67(8):3719-26. 
10. Malanchère-Brès $E$, Payette $P J$, Mancini $M$, Tiollais $P$, Davis $H L$, Michel ML. CpG oligodeoxynucleotides with hepatitis B surface antigen ( $\mathrm{HBs} A g$ ) or vaccination in HBsAg-transgenic mice. J Virol. 2001;75(14):6482-91.

11. Ivory CP, Keller K, Chadee K. CpG-oligodeoxynucleotide is a potent adjuvant with an Entamoeba histolytica gal-inhibitable lectin vaccine against amoebic liver abscess in gerbils. Infect Immun. 2006;74(1):528-36.

12. Klinman DM, Xie H, Ivins BE. CpG oligonucleotides improve the protective immune response induced by the licensed anthrax vaccine. Ann NYAcad Sci. 2006;1082(1):137-50

13. Alignani D, Maletto B, Liscovsky M, Ropolo A, Moron G, Pistoresi-Palencia MC. Orally administered OVA/CpG-ODN induces specific mucosal and systemic immune response in young and aged mice. J Leukoc Biol. 2005; 77(6):898-905.

14. Cooper CL, Davis HL, Morris ML, Efler SM, Krieg AM, Li Y, et al. Safety and immunogenicity of CPG 7909 injection as an adjuvant to Fluarix influenza vaccine. Vaccine. 2004;22:3136-43.

15. Xueju W, Musheng B, Min W, Hongfei W, Li W, Hongtao Y, et al. A CpG oligodeoxynucleotide acts as a potent adjuvant for inactivated rabies virus vaccine. Vaccine. 2008;26:1893-901.

16. Ren J, Sun L, Yang L, Wang H, Wan M, Zhang P, et al. A novel canine favored CpG oligodeoxynucleotide capable of enhancing the efficacy of an inactivated aluminum-adjuvanted rabies vaccine of dog use. Vaccine. 2010; 28:2458-64.

17. Nair AB, Jacob S. A simple practice guide for dose conversion between animals and human. Journal of Basic and Clinical Pharmacy. 2016;7(2):27-31.

18. WHO expert consultation on rabies: second report. Geneva: WHO; 2013. WHO-recommended post-exposure prophylaxis regimens, 58,

19. Xue-ju W, Jing L, Min W, Li W, Xiuli W, Hongfei W, et al. Determination of optimized MTT colorimetric assay as the identification method for the activity of B type CpG ODN BW006. Chin J Cell Mol Immunol. 2008; 24(1):69-71.

20. Sun S, Zhang X, Tough DF, Sprent J. Type I interferon-mediated stimulation of T cells by CpG DNA. J Exp Med. 1998;188:2335-42.

21. Chu RS, Targoni OS, Krieg AM, Lehmann PV, Harding CV. CpG oligodeoxynucleotides act as adjuvants that switch on Thelper (Th1) immunity. J Exp Med. 1997;186:1623-31.

22. McCluskie MJ, Davis HL. CpG DNA is a potent enhancer of systemic and mucosal immune responses against hepatitis B surface antigen with intranasal administration to mice. J Immunol. 1998;161:4463-6.

23. Hunolstein C, Mariotti S, Teloni R, Alfarone G, Romagnoli G, Orefici G, et al. The adjuvant effect of synthetic oligodeoxynucleotide containing CpG motif converts the anti-Haemophilus influenzae type b glycoconjugates into efficient anti-polysaccharide and anti-carrier polyvalent vaccines. Vaccine. 2001;19(23-24):3058-66

24. Kovarik J, Bozzotti P, Love-Homan L, Pihlgren M, Davis HL, Lambert PH, et al. CpG oligonucleotides can cirmcuvent the $\mathrm{TH} 2$ polorization of neonatal responses to vaccines but fail to fully redirect $\mathrm{TH} 2$ responses established by neonatal priming. J Immunol. 1999;162:1611-7.

25. Eastcott JW, Holmberg CJ, Dewhirst FE, Esch TR, Smith DJ, Taubman MA Oligonucleotide containing CpG motifs enhances immune response to mucosally or systemically administered tetanus toxoid. Vaccine. 2001;19(1314):1636-42

26. Al Mariri A, Tibor A, Mertens $P$, De Bolle X, Michel P, Godefroid J, et al. Protection of BALB/C mice against Brucella abortus 544 challenge by vaccination with bacterioferritin or $\mathrm{P} 39$ recombinant proteins with $\mathrm{CpG}$ oligodeoxynucleotides as adjuvant. Infect Immun. 2001;69(8):4816-22.

27. Xie H, Gursel I, Ivins BE, Singh M, O'Hagan DT, Ulmer JB, et al. CpG oligodeoxynucleotides adsorbed onto polylactide-co- glycolide microparticles improve the immunogenicity and protective activity of the licensed anthrax vaccine. Infect Immun. 2005;73(2):828-33.

28. Fogg CN, Americo JL, Lustig S, Huggins JW, Smith SK, Damon I, et al. Adjuvant-enhanced antibody responses to recombinant proteins correlates with protection of mice and monkeys to orthopoxvirus challenges. Vaccine. 2007;25(15):2787-99.

29. Klinman DM, Currie D, Lee G, Grippe V, Merkel T. Systemic but not mucosal immunity induced by AVA prevents inhalational anthrax. Microbes Infect. 2007;9(12-13):1478-83.

30. Gallichan WS, Woolstencroft RN, Guarasci T, McCluskie MJ, Davis HL, Rosenthal KL. Intranasal immunization with CPG oligodeoxynucleotides as an adjuvant dramatically increases $\lg A$ and protection against herpes simplex virus-2 in the genital tract. J Immunol. 2001;166(5):3451-7.
31. Hemmi H, Takeuchi O, Kawai T, Kaisho T, Sato S, Sanjo H, et al. A toll-like receptor recognizes bacterial DNA. Nature. 2000;408:740-5.

32. Kadowaki N, Ho S, Antonenko S, Malefyt RW, Kastelein RA, Bazan F, et al. Subsets of human dendritic cell precursors express different toll-like receptors and respond to different microbial antigens. J Exp Med. 2001; 194(6):863-9.

33. Krug A, Towarowski A, Britsch S, et al. Toll-like receptor expression reveals CpG DNA as a unique microbial stimulus for plasmacytoid dendritic cells which synergizes with CD40 ligand to induce high amounts of IL-12. Eur J Immunol. 2001;31(10):3026-37.

34. Bauer M, Redecke V, Ellwart JW, Rothenfusser S, Hornung V, Bals R, et al. Bacterial CpG DNA triggers activation and maturation of human CD11C (-), CD123(+) dendritic cells. J Immunol. 2001;166(8):5000-7.

35. Krieg AM, Yi A, Matson S, Waldschmidt TJ, Bishop GA, Teasdale R, et al. CpG motifs in bacterial DNA trigger direct B-cell activation. Nature. 1995;374:546-8.

36. Marshall JD, Fearon K, Abbate C, Subramanian S, Yee P, Gregorio J, et al. Identification of a novel CpG DNA class and motif that optimally stimulate B cell and plasmacytoid dendritic cell functions. J Leukoc Biol. 2003;73(6):781-92.

37. Ballas ZK, Rasmussen WL, Krieg AM. Induction of NK activity in murine and human cells by CpG motifs in oligodeoxynucleotides and bacterial DNA. J Immunol. 1996;157:1840-7.

38. Halpern MD, Kurlander RJ, Pisetsky DS. Bacterial DNA induces murine interferon-g production by stimulation of $\mathrm{IL}-12$ and tumor necrosis factor-a. Cell Immunol. 1996;167:72-8.

39. Xu HL, Wang SQ, Wang SF, Guo F, Lu RJ, Li R. Evaluation of Immunostimulatory activities of human CpG-ODN containing 5'-GTCGTT-3' motif in murine model. Chinese Journal of Virology. 2001;17(1):43-7.

40. Cooper CL, Davis HL, Morris ML, Efler SM, Adhami MA, Krieg AM, et al. CPG 7909, an immunostimulatory TLR9 agonist oligodeoxynucleotide, as adjuvant to Engerix-BHBV vaccine in healthy adults: a double-blind phase I/ II study [J]. J Clin Immunol. 2004;24(6):693-701.

\section{Ready to submit your research? Choose BMC and benefit from:}

- fast, convenient online submission

- thorough peer review by experienced researchers in your field

- rapid publication on acceptance

- support for research data, including large and complex data types

- gold Open Access which fosters wider collaboration and increased citations

- maximum visibility for your research: over $100 \mathrm{M}$ website views per year

At BMC, research is always in progress.

Learn more biomedcentral.com/submissions 